(c) American Dairy Science Association, 2003.

\title{
Prediction of Dairy Housing Construction Costs
}

\author{
J. M. Pereira, ${ }^{\star}$ C. J. Álvarez, ${ }^{*}$ and M. Barrasa* \\ *Department of Agroforestry Engineering, \\ University of Santiago de Compostela, 27002 Lugo, Spain
}

\section{ABSTRACT}

Dairy farms in Galicia and elsewhere in Europe are going through a transition phase to adapt to modern dairy technology, improve labor efficiency, and increase in size and scale. Expanding a dairy herd and building housing for more cows can be very expensive. A poor decision during expansion can result in serious financial difficulties even to the point of making the farm economically unviable. Dairy managers must carefully evaluate existing alternatives and must select an optimal strategy. To aid this decision, a computer spreadsheet application has been developed that predicts the cost per cow and cost per unit of area of alternative designs as functions of the number of cows to be housed. The spreadsheet is, in principle, applicable to a wide variety of designs and to housing for livestock other than dairy cattle. However, the current database allows comparison among six of the dairy housing designs that have been used most widely in Galicia in recent years. From projected financial results of the developed model, it was concluded that differing designs were preferred for different farm circumstances. Preferred designs for farms with 60 to 200 cows were either four rows of facing free stalls or four rows of tail-to-tail free stalls, which have virtually the same costs. Whereas for farms with fewer than 60 cows, the preferred design was two rows of tail-to-tail free stalls, designs with three rows of free stalls were generally more costly per cow. Results of design calculations must be integrated with other farm management considerations in choosing a particular design. (Key words: dairy farm, investment, cost, design)

\section{INTRODUCTION}

Galicia, a Spanish autonomous community with over 3 million inhabitants, constitutes the northwestern corner of Spain (Figure 1).

Received July 15, 2002.

Accepted March 12, 2003.

Corresponding author: J. M. Peireira Gonzalez; e-mail: jpereira@ lugo.usc.es.
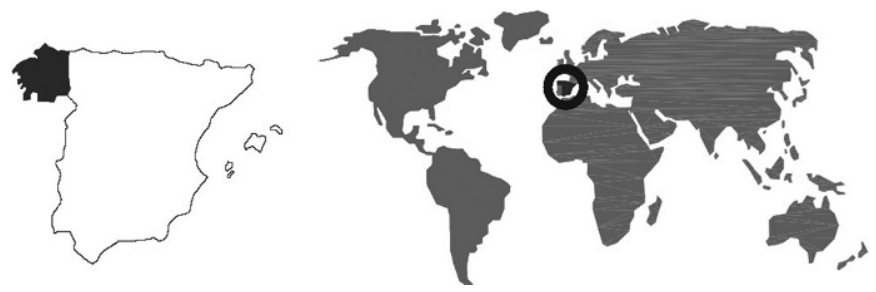

Figure 1. Geographical location of Galicia.

Galicia still includes some $40 \%$ of Spanish dairy farms even though drastic structural changes have reduced dairy farm numbers from nearly 137,000 to about 37,500 over the past $20 \mathrm{yr}$, while simultaneously increasing the number of cows per farm (Table 1).

Concentration of the dairy industry is still under way. For owners of surviving, expanding farms there is considerable economic outlay, particularly for construction of larger, more modern dairy housing. These changes, which are the result of adaptation of modern

Table 1. Distribution of Galician dairy farms by size in 1980 and 1999. ${ }^{1}$

\begin{tabular}{lcccc}
\hline & & \multicolumn{2}{c}{1999} \\
\cline { 1 - 2 } \cline { 5 - 5 } Cows/farm & No. of farms & & Cows/farm & No. of farms \\
\hline $1-4$ & 91,980 & & 1 to 19 & 22,767 \\
$5-9$ & 36,970 & & 20 to 49 & 11,088 \\
$\geq 10$ & 7,830 & & 50 to 99 & 3,164 \\
& & 100 to 199 & 445 \\
& & 200 to 299 & 42 \\
& & & 300 to 499 & 15 \\
Total & 136,780 & & Total & 37,525 \\
\hline
\end{tabular}

${ }^{1}$ Source: Instituto galego de estatística, 2000.

Table 2. Descriptions of the layouts of the six designs.

\begin{tabular}{ll}
\hline Design & Description \\
\hline T1 & Layout with two rows of facing free stalls \\
T2 & Double design of T1 with four rows of facing free stalls \\
T3 & Layout with two rows of tail to tail free stalls \\
T4 & Double design of T3 with four rows of tail to tail \\
& free stalls \\
T5 & Layout with three rows of free stalls \\
T6 & Layout with three rows of free stalls \\
\hline
\end{tabular}




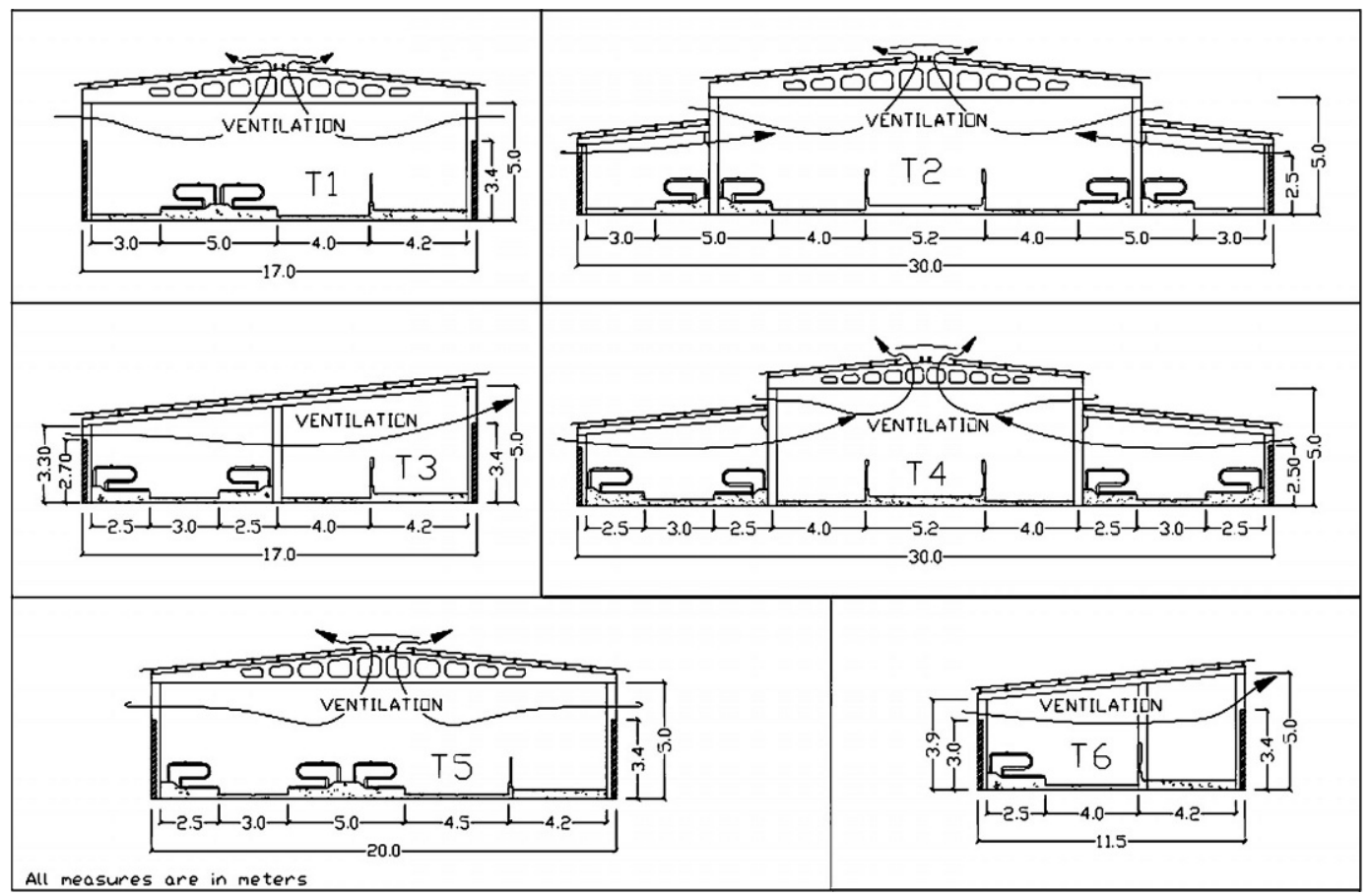

Figure 2. Transverse sections through the six free-stall barn designs considered in this study.

Table 3. Characteristics common to the free stall barn designs considered.

\begin{tabular}{|c|c|c|}
\hline Characteristic & \multicolumn{2}{|l|}{ Type chosen } \\
\hline Site level & \multicolumn{2}{|c|}{600 to $800 \mathrm{~m}$ above sea level, normal wind exposure (NTE-ECV zone X) } \\
\hline Ventilation & \multicolumn{2}{|c|}{ Natural ventilation } \\
\hline Structure & \multirow{2}{*}{\multicolumn{2}{|c|}{$\begin{array}{l}\text { Prefabricated reinforced concrete beams rooted in square pier footings } \\
95 \% \text { corrugated fiber cement sheets, } 5 \% \text { translucent corrugated sheets, } \\
\text { slope } 10 \% \text {, ridge cap ventilation }\end{array}$}} \\
\hline Roofing & & \\
\hline Walling & \multicolumn{2}{|c|}{ Breeze blocks } \\
\hline Flooring & \multicolumn{2}{|c|}{ Concrete over stone chips } \\
\hline Stalls & \multicolumn{2}{|c|}{ Freestalls, hot-dip galvanized steel tubing dividers } \\
\hline Cleaning equipment & \multirow{2}{*}{\multicolumn{2}{|c|}{$\begin{array}{l}\text { Automatic scraper } \\
\text { Galvanized iron sheeting }\end{array}$}} \\
\hline Fittings & Galvanized iron she & \\
\hline Measurements & Symbol & Value $(\mathrm{m})$ \\
\hline Number of stalls rows & $N_{\mathrm{F}}$ & According to design (Figure 2) \\
\hline Number of cows & $N$ & $N=$ Number of stalls \\
\hline Stall length & $L_{\mathrm{CU}}$ & 2.5 \\
\hline Stall width & $A_{\mathrm{CU}}$ & 1.25 \\
\hline Feed-space width & $L_{\mathrm{CO}}$ & 0.75 \\
\hline Transverse alley width & $A_{\mathrm{PC}}$ & $\geq 2.5$ (but constant) \\
\hline Number of transverse alleys & $N_{\mathrm{PC}}$ & At least one per 20 stalls per row \\
\hline Feed alley width & $A_{\mathrm{PRA}}$ & 4.0 to 4.5 \\
\hline Free-stall alley width & $A_{\mathrm{PRP}}$ & 3.0 \\
\hline Width of feed table(s) & $A_{\mathrm{PA}}$ & 4.2 (table + driveway) \\
\hline plus driveway & & $5.2($ table + driveway + table $)$ \\
\hline Total interior width & $A_{\text {INT }}$ & $A_{\mathrm{INT}}=L_{\mathrm{CU}} N_{\mathrm{F}}+A_{\mathrm{PRA}}+A_{\mathrm{PRP}}+A_{\mathrm{PA}}$ \\
\hline Total interior length & $L_{\mathrm{INT}}$ & $L_{\mathrm{INT}}=N A_{\mathrm{CU}} / N_{\mathrm{F}}+N_{\mathrm{PC}} A_{\mathrm{PC}}$ \\
\hline Column width & $E_{\mathrm{P}}$ & 0.3 to 0.4 \\
\hline Between column distances & Sep & $S e p=\left(L_{\mathrm{INT}}+E_{\mathrm{P}}\right) / N_{\mathrm{V}}$ \\
\hline Column-to-column bays & $N_{\mathrm{V}}$ & Function of $S e p$ (6 to 7) and $L_{\mathrm{INT}}$ \\
\hline
\end{tabular}



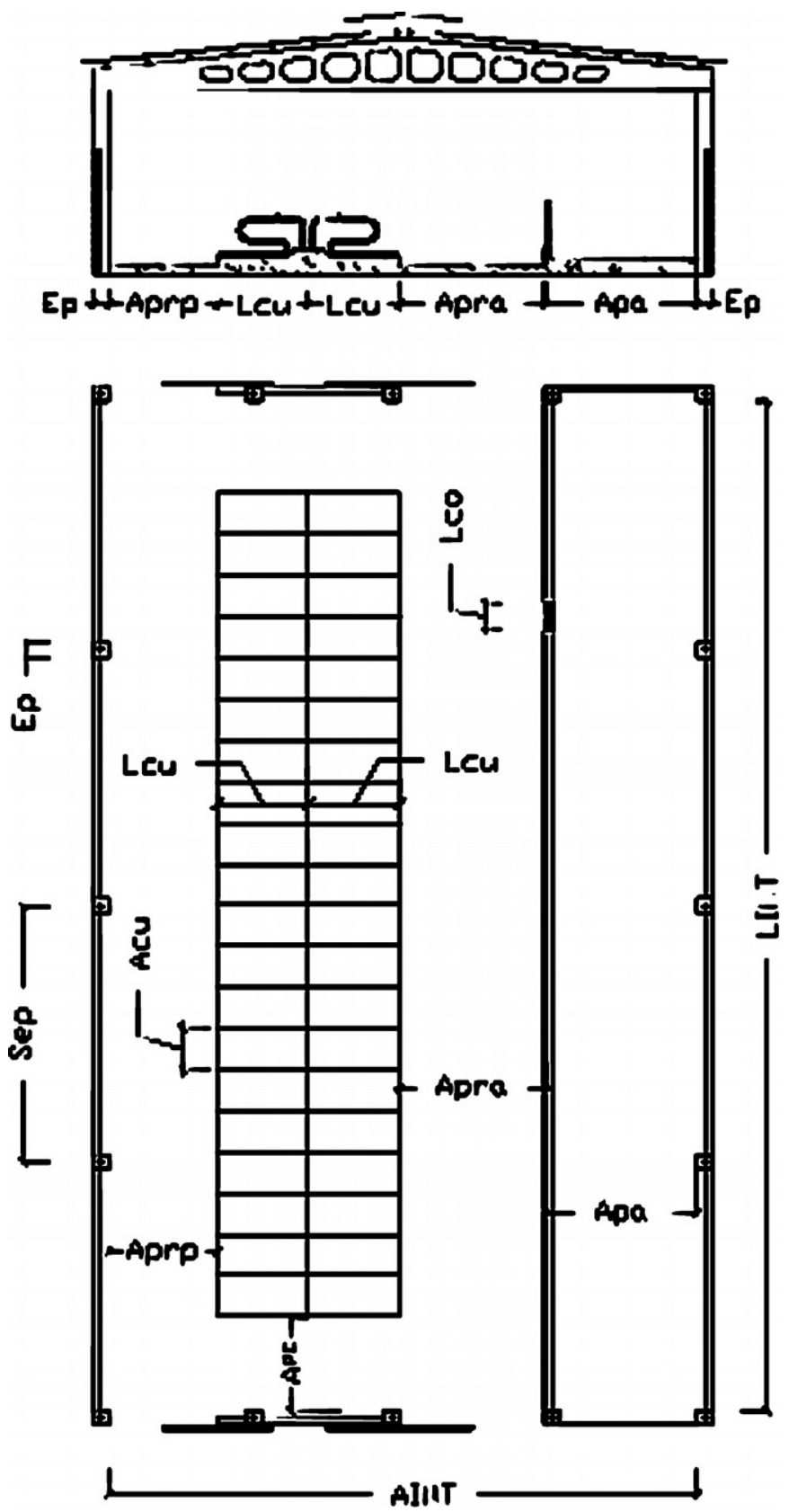

Figure 3. Relationships among geometrical parameters.

dairy technology, are intended to allow dairy managers to operate with lower investment per cow and to improve the quality of life of the dairy farm owners and workers. To be successful, the manager should attempt to develop business plans and facilities that are flexible. All facilities should be designed to allow for future expansion, plus offer safe and comfortable conditions for both the animals and workers (Palmer, 1999).
The choice of the design and size of dairy housing influences at least three factors affecting production and costs: the environmental conditions and productivity of the cattle, the efficiency of operations, and financial costs (Karzes, 2000). The influence of various environmental factors on the health and productivity of cattle has been confirmed by numerous authors (e.g., Hill et al., 1973; Harmon et al., 1992; Longenbach et al., 1999; Miller et al., 2000). The efficiency of operations is continually increasing thanks to improvements in equipment, in the working conditions of farm workers [for the importance of adequate lighting, see Beck (1995)] and in management systems [see, for example, Longenbach et al. (1999) on feed bunk requirements, and Meyer et al. (1999) on manure management]. The importance of comparing investment options as regards their associated financial costs has been stressed by many (see, for example, Ministère de l'agriculture, 1982; Hives, 1985; Hartmann, 1995; Kobayashi et al., 2000; and Mariño, 2001).

One of the decisions most critical for final construction costs is the initial choice of basic design (Trueba and Marco, 1986). To aid this decision, we have developed a computer spreadsheet application that predicts the cost per cow and cost per unit area of particular designs as functions of the number of cows to be housed. Although in principle applicable to a wide variety of designs, and to housing for livestock other than dairy cattle, its current database allows comparison among six of the dairy housing designs that have been used most widely in Galicia in recent years.

\section{MATERIALS AND METHODS}

On the basis of examination of all the dairy housing facilities constructed in Galicia in the period 1997 to 2000 , and given the impossibility of taking all possible construction variables into account, we chose to analyze the six free-stall barn designs shown in Figure 2 and Table 2 assuming common specifications for siting, materials, basic equipment, and unit measurements; Table 3 and Figure 3 list some of the more important of these factors.

The siting and structural characteristics and measurements indicated in Table 3 were used, assuming between-column distances Sep of 6 to $7 \mathrm{~m}$, to calculate the parameters and stresses of beams, purlins, and columns in accordance with Spanish official building regulations (Ministerio de Fomento, 1999: EHE Art. 42, 43, 59; Ministerio de Fomento, 1993). In the event, in the $S e p$ range considered $S e p$ proved not to influence column width $E_{\mathrm{P}}$, and $S e p$ was accordingly calculated as the largest distance in the range 6 to $7 \mathrm{~m}$ that was compatible with the geometrical relationship. 
T-2 FREESTALL BARN DESIGN BUDGET

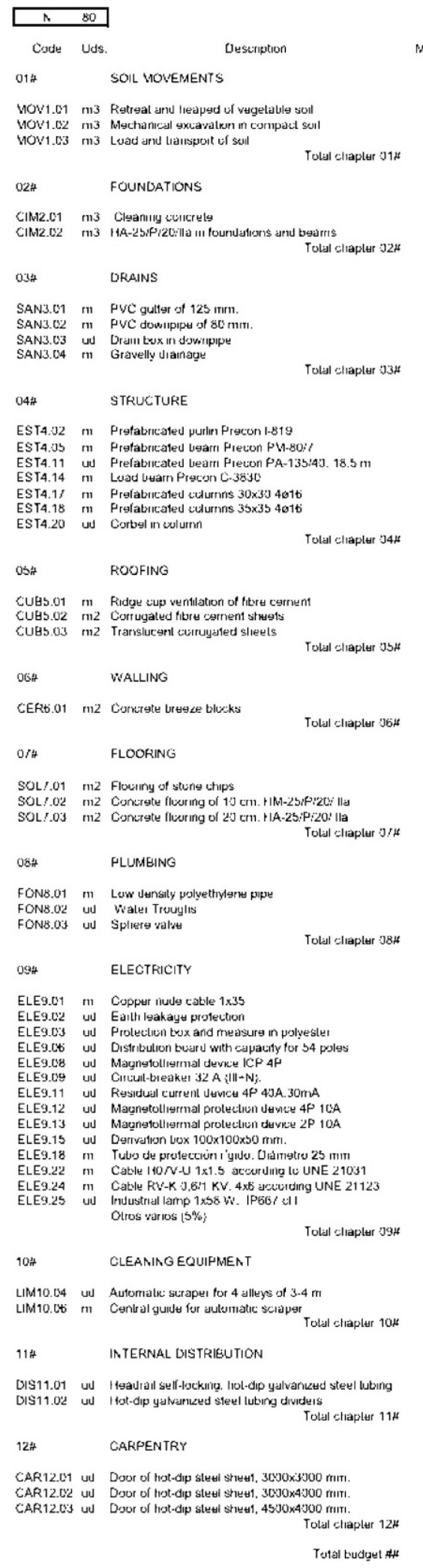

\begin{tabular}{|c|c|c|}
\hline \multirow[b]{2}{*}{$\begin{array}{l}\text { Measurg- } \\
\text { misnil }\end{array}$} & Stpp & 6.08 \\
\hline & $\begin{array}{l}\text { Prive } \\
\text { (Eurus! }\end{array}$ & $\begin{array}{l}\text { Arnount } \\
\text { (Eurus! }\end{array}$ \\
\hline 314.88 & 1.36 & 428.24 \\
\hline 52.10 & 6. 76 & 352.20 \\
\hline 366.98 & 2.60 & $\begin{array}{r}954.15 \\
1.7 / 44.59\end{array}$ \\
\hline 8.44 & 48.08 & 435.80 \\
\hline 43.66 & 111.19 & $\begin{array}{l}\text { 4. } 854.56 \\
\text {. } 260.36\end{array}$ \\
\hline 51.60 & 6.61 & 431.18 \\
\hline 36.00 & 6.01 & 216.36 \\
\hline 12.00 & 45.08 & 543.96 \\
\hline E1.60 & 3.01 & $\begin{array}{r}185.42 \\
1349.92\end{array}$ \\
\hline & & 1.399 .92 \\
\hline 924.00 & 3.88 & 3.585 .12 \\
\hline 4.80 & 64.91 & $311.5 /$ \\
\hline 3.00 & $15 \mathrm{~d} J .0$ & 1.535 .00 \\
\hline 156.00 & 24.73 & 2.621 .38 \\
\hline 36.00 & 39.07 & 1.4.J6.52 \\
\hline 80.00 & 43.15 & 3.452 .00 \\
\hline 18.00 & 51.09 & 419.62 \\
\hline & & 19.831 .21 \\
\hline
\end{tabular}

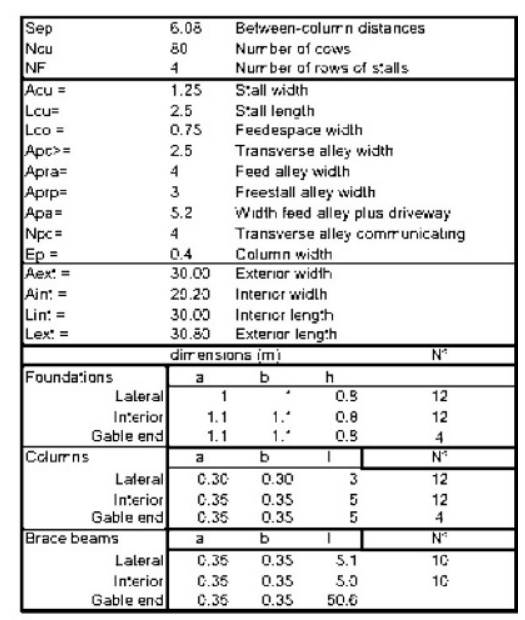

$\begin{array}{rrr}33.80 & 16.83 & 518.36 \\ 817.80 & 11.82 & 9.491 .80 \\ 46.20 & 16.83 & 111.55 \\ & & 10 . / 43.71\end{array}$

GABLEEND

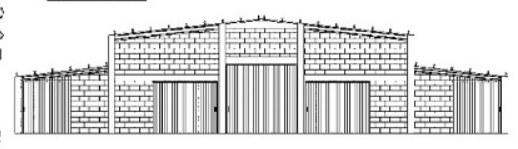

$301.00 \quad 16.92 \quad \begin{array}{r}5.092 .92 \\ 5.042 .92\end{array}$

$\begin{array}{rrr}8 / 6.00 & 4.10 & 3.501 .60 \\ 72.00 & 19.22 & 7.356 .40 \\ 156.00 & 21.04 & 3.262 .24\end{array}$

$\begin{array}{rr}156.00 & 21.04 \quad 3.282 .24 \\ & 14.232 .24\end{array}$

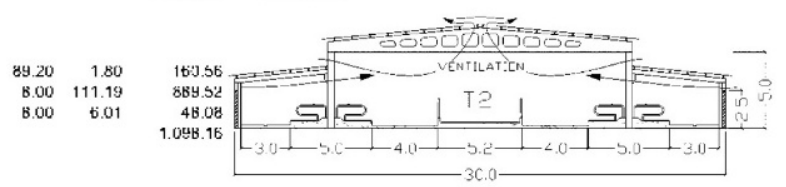

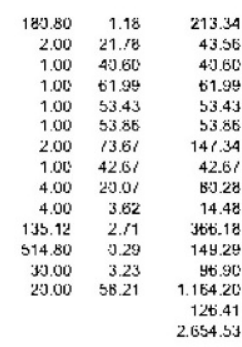

$1.00 \quad 12,140$

$\begin{array}{rr}1.00 & 12,140 \\ 131.20 & 33.06\end{array}$

12.140 .00

$4.331 .4 /$

PLANT (example for $N=80$ )

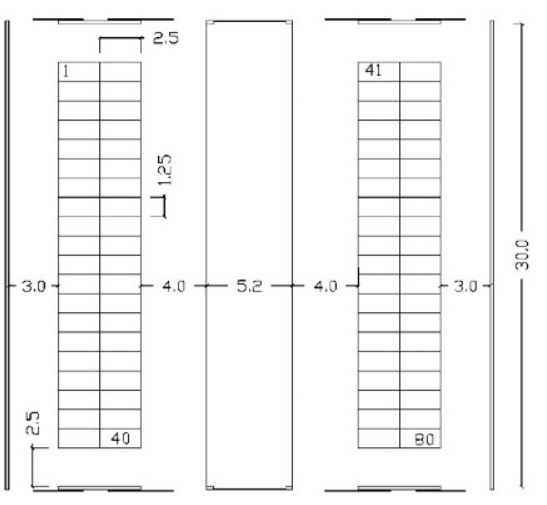

Figure 4. Spreadsheet analysis of design T2 for an 80-cow barn. 


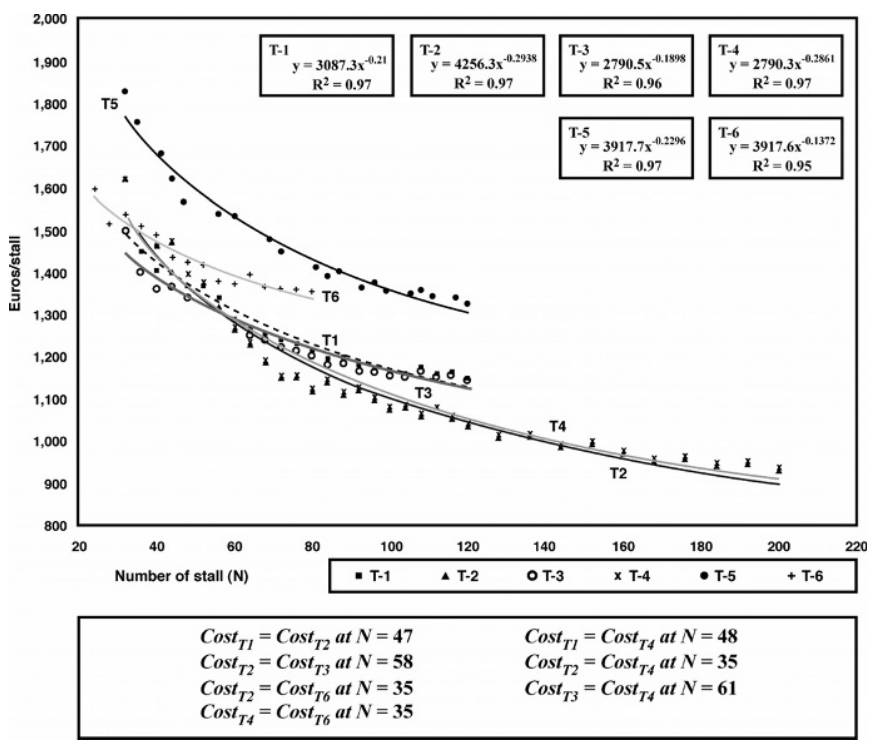

Figure 5. Calculated costs per stall of the six designs considered, together with the equations of the corresponding fitted curves and their points of intersection.

With measurements and quantitative structural characteristics in hand, the corresponding construction work was analyzed into costing units for the purposes of cost estimation (Ramírez, 1997). Whenever possible, units and the corresponding unit costs were taken from available Spanish databases for estimating costs (Barrasa, 1999). For work for which no available data base featured an applicable costing unit, ad hoc

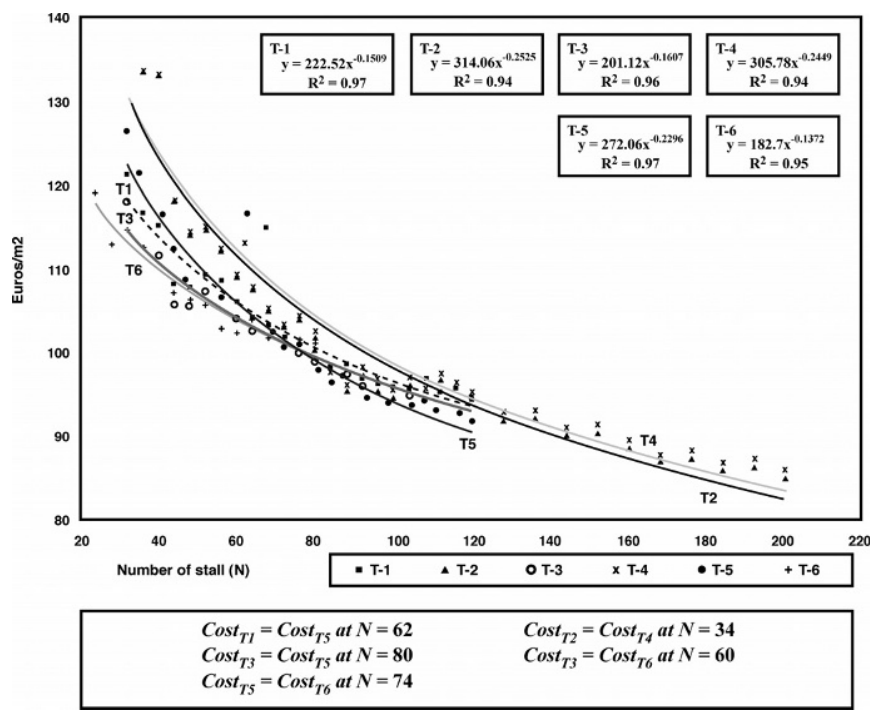

Figure 6. Calculated costs per square meter of barn of the six designs considered, together with the equations of the corresponding fitted curves and their points of intersection. units were defined, cost estimates were obtained from a panel of 14 construction industry professionals, and the estimate nearest to the mean of the 14 was adopted as the unit cost. The cost information is based on prices in the year 2000 .

A spreadsheet application was then written that, given one of the designs of Figure 2, calculates 1) the measurements of foundations and footings for given $E_{\mathrm{P}}$ and $\left.S e p, 2\right)$ unit costs for given $N$, and 3) total estimated cost for given $N$ (Figure 4).

\section{RESULTS AND DISCUSSION}

Figure 5 shows the costs of designs T1 to T6 per stall for various values of $N$ between 20 and 200 (depending on design), together with fitted curves of the form Cost $=a N^{b}$, the equations and coefficients of determination of these curves, and the values of $N$ at which the curves intersect each other.

Figure 6 shows analogous data for the cost per square meter of barn. In both cases, costs naturally decrease as $N$ increases due to the spreading of fixed costs among a larger number of stalls or over a larger surface area; the cost per stall of design T2, for example, is almost $60 \%$ less expensive for a 200 -stall barn than for a 40-stall barn. The main fixed costs correspond to the scraper and the structure and fittings of the end walls. The scraper also contributes significantly to the differences in cost among the various designs, because the cost of the scraper depends on the number and surface area of the alleys to be cleaned. The costs of different designs for the same number of stalls differ by up to $25 \%$, depending on the number of stalls (although costs per square meter differ by no more than $16 \%$ ).

Although not addressed specifically in the current study, optimal housing designs for herds larger than 200 cows might differ from the alternatives examined herein.

\section{CONCLUSIONS}

From the results of the developed model, it may be concluded that preferred designs for farms with 60 to 200 cows are T2 (four rows of facing free stalls) or T4 (four rows of tail-to-tail free stalls), which have virtually the same costs, whereas for farms with fewer than 60 cows, the preferred design was T3 (two rows of tail-to-tail free stalls). In general, the results of the calculations must be integrated with other considerations in choosing a particular design. Lastly, total construction costs need to include items such us milking parlor or dung storage; without those a dairy housing system is not completely defined. 


\section{REFERENCES}

Barrasa, M. 1999. La presupuestación en los proyectos de ingeniería agroforestal. Problemática y propuestas: Aplicación a los proyectos de caminos rurales. (PhD Thesis). Escuela Politécnica Superior de Lugo, Universidad de Santiago de Compostela, Lugo, Spain.

Beck, L. 1995. Good reasons for light upgrades. Engineer's Digest. September:34-38.

Harmon, R. J., T. Clark, T. Ramesh, W. L. Crist, B. E. Langlois, K. Akers, and B. Smith. 1992. Environmental pathogen numbers in pastures and bedding of dairy cattle. J. Dairy Sci. 75(Suppl. 1):256. (Abstr.)

Hartmann, W. 1995. Kostenvergleich von Stallneubauten für gröBere Milchviehbestände. Bauen Fuer Die Landwirtschaft, 2/ 95:18-21.

Hill, D. L., N. J. Moeller, D. H. Yungblut, C. E. Parmelee, and J. L. Albright. 1973. The effect of two different housing systems upon milk production, milk quality, health and behavior of dairy cows. J. Dairy Sci. 56:688. (Abstr.)

Hives, J. K. 1985. Cost implications of design options. Farm Buildings Eng. 2(2):10-14.

Instituto Galego de Estatística. 2000. Enquisa de explotacións de vacún en Galicia. Xunta de Galicia, Spain.

Karzes, J. 2000. Facilities and the bottom line. Pages 13-19 in Dairy Housing and Equipment Systems. NRAES-129, Ithaca, NY.

Kobayashi, T., T. Tomabechi, and S. Hoshiba. 2000. Analysis on construction costs of livestock buildings in cold snowy region. J. Soc. Agric. Structures 2000:43-50). Japan.
Longenbach, J. I., A. J. Heinrichs, and R. E. Graves. 1999. Feed bunk length requirements for Holstein dairy heifers. J. Dairy Sci. 82:99-109.

Mariño, R. 2001. Aplicaciones de la madera en las construcciones agrarias de Galicia. Análisis y optimización de tipologías estructurales. Ph.D. Thesis. Universidad de Santiago de Compostela. Escuela Politécnica Superior de Lugo. Lugo, Spain.

Meyer, J. D. 1999. In-Barn Manure Management Options. Cooperative Extension for Iowa State University, U. of Illinois, U. of Minnesota, and U. of Wisconsin, MWPS-4SD4, 45-49.

Miller, A. R. E., R. A. Erdman, L. W. Douglass, and G. E. Dahl. 2000. Effects of photoperiodic manipulation during the dry period of dairy cows. J. Dairy Sci. 83:962-967.

Ministère de L'Agriculture. 1982. Etables pour vaches laitières, Plans-exemples et dèvis. Dossier 1:45-50 vaches laitières. Ministère de L’Agriculture. París, France.

Ministerio de Fomento. 1993. Normas Tecnológicas de Edificación (NTE). Ministerio de Fomento, Madrid, Spain.

Ministerio de Fomento. 1999. Instrucción de Hormigón Estructural (EHE). Ministerio de Fomento, Madrid, Spain.

Palmer, W. R. 1999. Modernization Options. Cooperative Extension for Iowa State University, U. of Illinois, U. of Minnesota, and U. of Wisconsin, MWPS-4SD4, 9-12.

Ramírez, A. 1997. Seminario de presupostación de proxectos. Estructura de costos. EPS (Proxecto Columella). Lugo, Spain.

Trueba, I., and J. L. Marco. 1986. Proyectos Agrarios y de Desarrollo Rural. E. T. S. I. Agrónomos, Universidad Politécnica de Madrid, Madrid, Spain. 